\title{
Correction to: Proteotranscriptomics assisted gene annotation and spatial proteomics of Bombyx mori BmN4 cell line
}

Michal Levin ", Marion Scheibe and Falk Butter ${ }^{*}$

\section{Correction to: BMC Genomics 21, 690 (2020) \\ https://doi.org/10.1186/s12864-020-07088-7}

Following publication of the original article [1], it was reported that there were errors in Figs. 1 and 2. The correct figures are included in this Correction article and the original article has been updated.

Published online: 12 November 2020

\section{Reference}

1. Levin M, Scheibe M, Butter F. Proteotranscriptomics assisted gene

annotation and spatial proteomics of Bombyx mori BmN4 cell line. BMC Genomics. 2020;21:690 https://doi.org/10.1186/s12864-020-07088-7.

The original article can be found online at https://doi.org/10.1186/s12864 020-07088-7.

*Correspondence: m.levin@imb.de; f.butter@imb.de

Institute of Molecular Biology (IMB), Ackermannweg 4, 55128 Mainz,

Germany

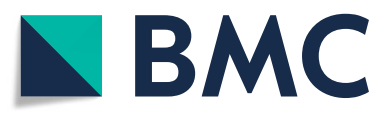

(- The Author(s). 2020 Open Access This article is licensed under a Creative Commons Attribution 4.0 International License, which permits use, sharing, adaptation, distribution and reproduction in any medium or format, as long as you give appropriate credit to the original author(s) and the source, provide a link to the Creative Commons licence, and indicate if changes were made. The images or other third party material in this article are included in the article's Creative Commons licence, unless indicated otherwise in a credit line to the material. If material is not included in the article's Creative Commons licence and your intended use is not permitted by statutory regulation or exceeds the permitted use, you will need to obtain permission directly from the copyright holder. To view a copy of this licence, visit http://creativecommons.org/licenses/by/4.0/ The Creative Commons Public Domain Dedication waiver (http://creativecommons.org/publicdomain/zero/1.0/) applies to the data made available in this article, unless otherwise stated in a credit line to the data. 


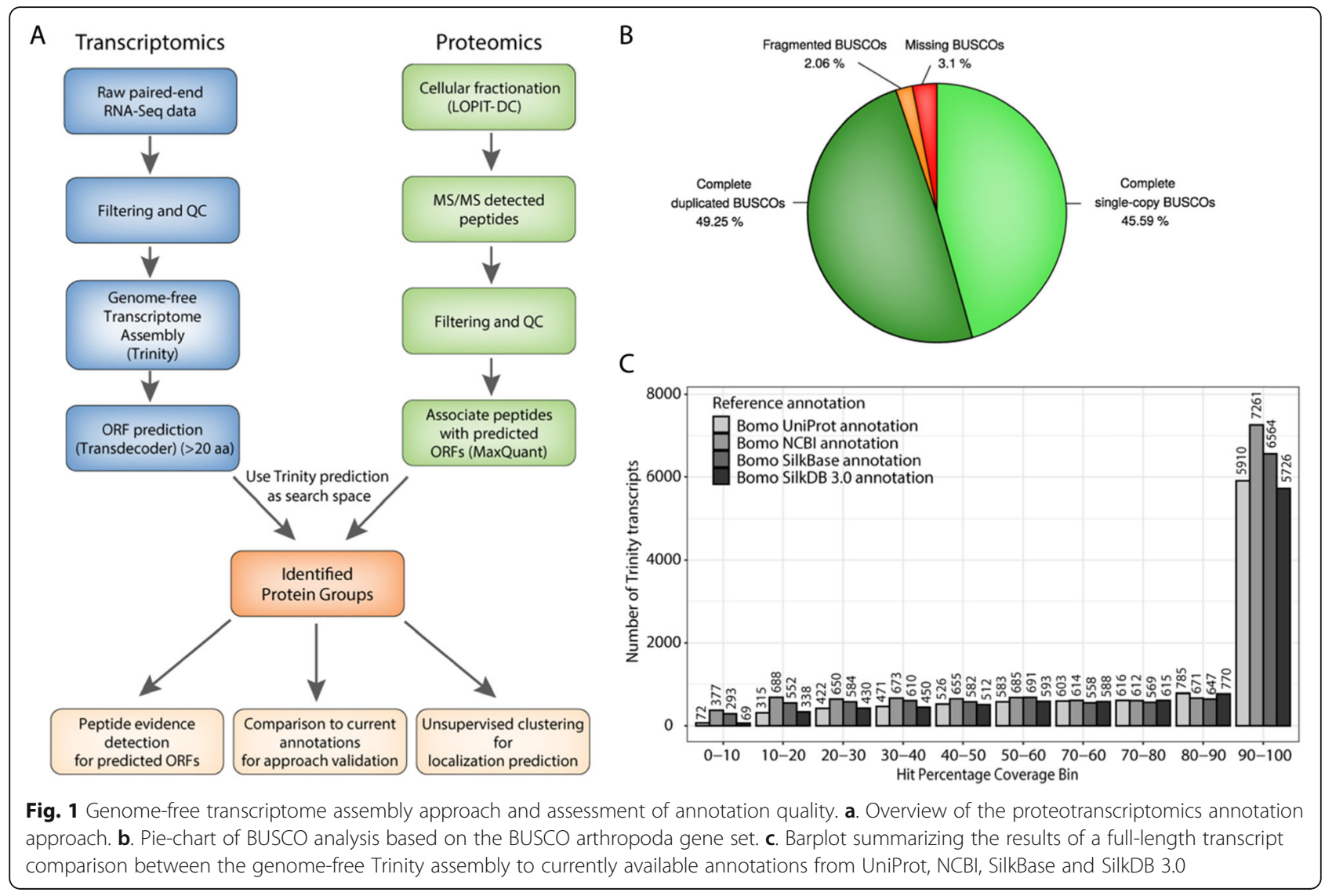




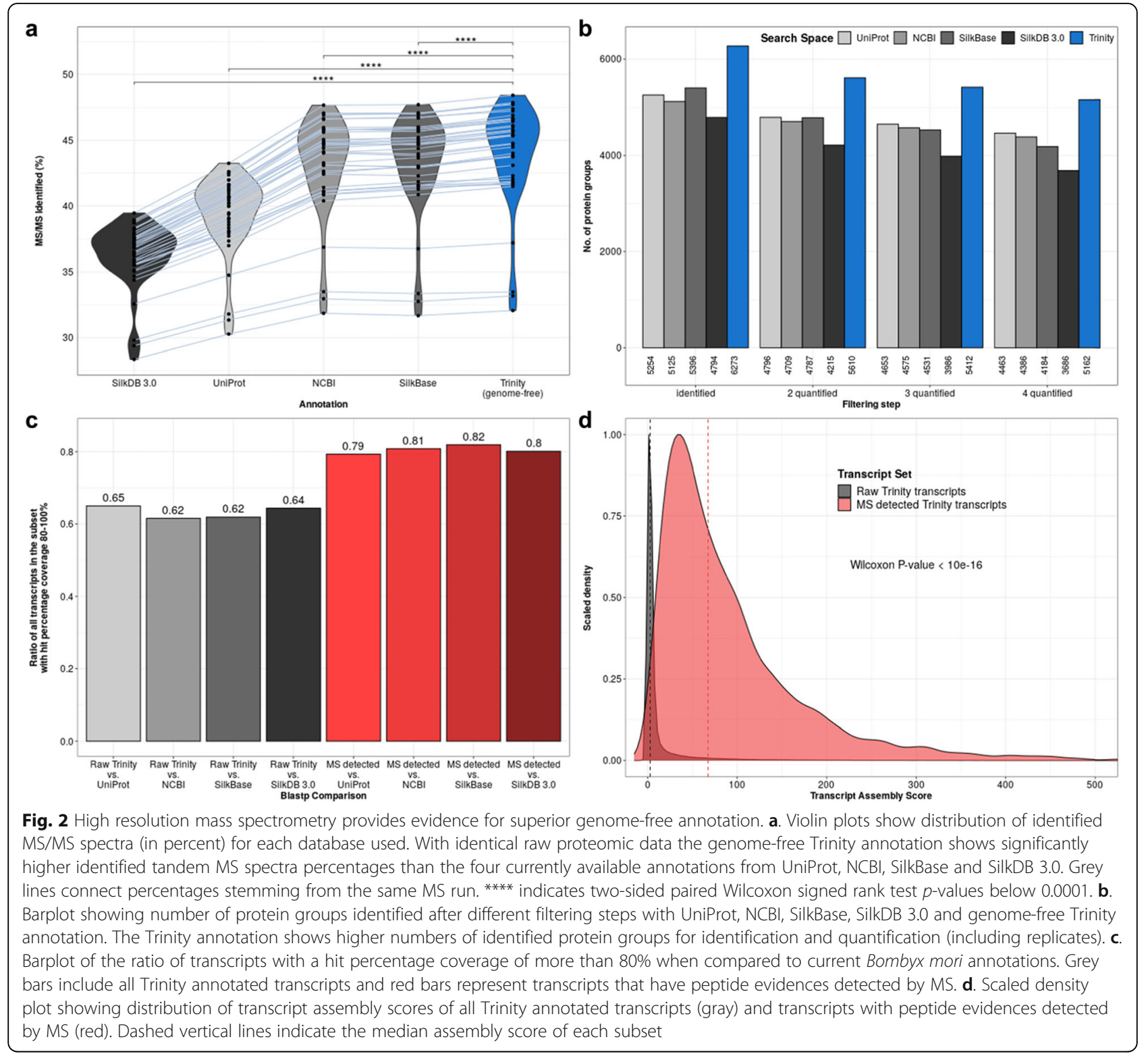

